micro-organisms are deprived of iron either directly or indirectly through competition of unsaturated iron binding proteins of the host (although it would be difficult to explain recrudescences of malaria on this basis). Alternatively the iron might create an intracellular milieu unfavourable to rapid multiplication of the micro-organisms or host cells essential for clinical infection or suppress the inflammatory response of the host to infection. We have looked at this mostly from a negative point of view-that is, supposing that the organism is deprived of something that prevents it producing disease-but the phenomenon might equally possibly be a positive one-that is, host cells during iron deprivation may produce a chalone-like material that reduces host cellular DNA replication in an effort to conserve dwindling food reserves. Such a mechanism might also fortuitously prevent the intracellular multiplication of the infecting agent. Our studies with Listeria monocytogenes and $P$ berghei in hypoferraemic, normoferraemic, and hyperferraemic mice $^{9}$ and those of Puschman and Ganzoni with $S$ typhimurium in mice similarly treated ${ }^{10}$ showed a substantial reduction of mortality in hypoferraemic animals. The repletion of the host with iron might therefore quickly reverse these changes, permitting unbridled division of organisms and overt clinical signs of infection.

We believe that iron deficiency in Somali nomads may be part of an ecological compromise. Animal milk, deficient in iron and often short in supply, causes chronic iron deficiency in nomads, who consume milk as their major source of energy. The iron deficiency, debilitating in some but rarely fatal, prevents the more serious consequences of potentially fatal infections with malaria, tuberculosis, and brucellosis to which the nomads are constantly exposed. A balance is struck whereby the nomads are able to co-survive with their micropredators at the price of their combined iron deficiency. We would like to end on a note of caution. It may be unwise to attempt to correct iron deficiency in the face of quiescent infection, especially in isolated societies where the natural ecological balance is often a first line of defence against severe infections.

\section{References}

1 Trousseau, A, Lectures on Clinical Medicine, p 96. London, New Sydenham Society, 1872.

${ }^{2}$ Chandra, R K, et al, in Iron Metabolism, Ciba Foundation Symposium 51, New Series, p 249. Amsterdam, Elsevier, 1977.

3 World Health Organisation, Control of Nutritional Anaemia with Special Reference to Iron Deficiency, p 580. Geneva, World Health Organisation, 1975.

${ }^{4}$ Lapiccerella, V, et al, Bulletin of the World Health Organisation, 1962, 27, 681.

${ }^{5}$ Murray, M J, and Murray, A B, Lancet, 1977, 1, 123.

6 Nelson, C V, American fournal of Medical Technology, 1964, 30, 71.

' Herbert, V, et al, fournal of Laboratory and Clinical Medicine, 1966, 67, 855.

${ }^{8}$ Klatersky, J, et al, fournal of Infectious Diseases, 1974, 129, 187.

${ }^{9}$ Murray, M J, and Murray, A B, in Third International Symposium on Trace Element Metabolism. In press.

${ }^{10}$ Puschman, M, and Ganzoni, A M, Infection and Immunology, 1977, 17, 633.

(Accepted 18 fuly 1978)

\title{
How often should patients be reviewed after treatment with iodine-131 for thyrotoxicosis?
}

\author{
A D TOFT, W J IRVINE, J SETH, E H D CAMERON
}

British Medical fournal, 1978, 2, 1115-1117

\section{Summary and conclusions}

Six to 18 years after treatment with iodine-131 for thyrotoxicosis 69 euthyroid patients with raised serum thyrotrophin (TSH) concentrations (mean 25.0 SE $2.0 \mathrm{mU} / 1$ ) and 61 with normal concentrations (mean $4.0 \pm 0.2 \mathrm{mU} / 1$ ) were included in a prospective five-year follow-up study beginning in 1972 . During this period 13 patients from the original group with raised serum TSH concentrations became hypothyroid. In contrast it was five years before hypothyroidism developed in a single patient from the group with normal serum TSH concentrations in 1972, although raised concentrations were recorded in 19 of these patients during the study.

\footnotetext{
Endocrine Unit and University Department of Medicine, Royal Infirmary, Edinburgh EH3 9YW

A D TOFT, MD, MRCP, senior registrar

W J IRVINE, DSC, FRCP, reader

University Department of Clinical Chemistry, Edinburgh J SETH, PHD, lecturer

Regional Hormone Laboratory, Edinburgh EH1 1ED E H D CAMERON, PHD, FRIC, director
}

Serum TSH concentrations may be used to assess how often patients need to be reviewed after iodine-131 treatment for thyrotoxicosis, thus greatly reducing the present long-term follow-up commitment in these cases.

\section{Introduction}

Iodine-131 is the most widely used treatment of thyrotoxicosis in patients over 40. A major disadvantage of this treatment, however, is the increasing incidence of thyroid failure with time. Since we cannot predict either when or in whom hypothyroidism will develop such patients need to be followed up for life or until thyroxine replacement therapy is started. In the United Kingdom alone over 60000 thyrotoxic patients have been treated with iodine-131 since the early 1950s and some 3000 new patients are added yearly. It would therefore be advantageous if follow-up of this ever-increasing number of patients could be reduced by utilising currently available tests of thyroid function. The serum thyrotrophin (TSH) concentration is a sensitive indicator of thyroid failure, and about half of all euthyroid patients treated with iodine-131 for thyrotoxicosis have raised TSH concentrations and thus impaired reserve of thyroid function. ${ }^{12}$ To determine any difference in clinical course between euthyroid patients with normal TSH concentrations and those with raised values we studied two such groups prospectively over five years between 1972 and 1977. 


\section{Patients and methods}

In 1972 serum total thyroxine (T4) and TSH concentrations were measured in 233 euthyroid patients who during 1954-66 had been treated in the endocrine unit with iodine-131 for thyrotoxicosis. Serum TSH was increased in $136(58 \%)$ of the patients and normal in $97(42 \%)$. We decided to estimate thyroid function prospectively in these two groups. On a geographical basis only, 69 patients ( 56 women, 13 men) with raised serum TSH concentrations and 61 (49 women, 12 men) with normal concentrations were selected for the follow-up study. The mean ages of the two groups in 1977 were $66.0 \pm$ SE 0.9 and $65.0 \pm 0.9$ years respectively. With the exception of 1973 , when the normal serum TSH group was not studied, the patients were assessed clinically by one observer (ADT) each year for five years between 1972 and 1977. At each assessment blood was taken for measurement of serum total T4, triiodothyronine (T3) (1975-7 only), and TSH concentrations. Hypothyroidism was diagnosed clinically and on the basis of low serum total T4 and raised serum TSH concentrations.

Serum total T3 and T4 were measured by specific radioimmunoassays. ${ }^{3}$ Interassay precision with anonymous control sera averaged $7.9 \%$ for $\mathrm{T} 3$ and $11.7 \%$ for $\mathrm{T} 4$, being expressed as coefficients of variation. Normal ranges for serum total T3 were $1 \cdot 1-2 \cdot 2 \mathrm{nmol} / \mathrm{l}$ $(0 \cdot 7-1 \cdot 4 \mathrm{ng} / \mathrm{ml})$ for men and $1 \cdot 1-2 \cdot 6 \mathrm{nmol} / \mathrm{l}(0 \cdot 7-1 \cdot 7 \mathrm{ng} / \mathrm{ml})$ for women, and for serum total T4 $60-150 \mathrm{nmol} / \mathrm{l}(4 \cdot 7-11 \cdot 7 \mu \mathrm{g} / 100 \mathrm{ml})$ for both sexes. During 1972-4 serum total T4 was measured by competitive protein-binding analysis, the results showing no significant difference from those obtained by radioimmunoassay. Serum TSH was measured by radioimmunoassay (reference preparation MRC H-TSH standard 68/38), in which the between-assay coefficient of variation was $11.2 \%{ }^{4}$ and the upper limit of normal at the outset of the study was $7.4 \mathrm{mU} / 1$. Although the upper limit of normal is now $5 \cdot 7 \mathrm{mU} / 1,^{5}$ the figure of $7.4 \mathrm{mU} / \mathrm{l}$, on which the original separation of the two groups of patients was based, was used throughout.

\section{Results}

Table I gives the mean serum total T4, T3, and TSH concentrations in the 69 euthyroid patients with raised TSH concentrations in 1972 and in those remaining euthyroid and available for study up to 1977. Clinical hypothyroidism developed in 13 of these patients during the study. Fifteen patients were lost to follow-up, seven of whom died. Table II gives the mean serum total T4, T3, and TSH concentrations in the 61 euthyroid patients with normal serum TSH

TABLE I-Mean serum total T4, T3, and TSH concentrations ( $\pm S E$ ) in euthyroid patients with high serum TSH concentrations in 1972 and in patients remaining euthyroid and available for study over next five years (all treated with iodine-131 for thyrotoxicosis between 1954 and 1966)

\begin{tabular}{|c|c|c|c|c|c|c|}
\hline Year & $\begin{array}{c}\text { No of } \\
\text { patients }\end{array}$ & $\underset{(\mathrm{nmol} / \mathrm{l})}{\operatorname{Serum~T4}}$ & $\underset{(\mathrm{nmol} / \mathrm{l})}{\operatorname{Serum} \mathrm{T}}$ & $\underset{\substack{\text { TSH } \\
(\mathrm{mU} / \mathrm{l})}}{\text { Serum }}$ & $\begin{array}{c}\text { No } \\
\text { developing } \\
\text { overt } \\
\text { hypo- } \\
\text { thyroidism }\end{array}$ & $\begin{array}{c}\text { No } \\
\text { lost to } \\
\text { follow-up }\end{array}$ \\
\hline $\begin{array}{l}1972 \\
1973 \\
1974 \\
1975 \\
1976 \\
1977\end{array}$ & $\begin{array}{l}69 \\
66 \\
61 \\
57 \\
46 \\
41\end{array}$ & $\begin{array}{l}88.0 \pm 1 \cdot 0 \\
84 \cdot 0 \pm 1 \cdot 0 \\
84.0 \pm 1 \cdot 0 \\
75.0 \pm 3 \cdot 0 \\
80.0 \pm 2 \cdot 6 \\
75 \cdot 0 \pm 2 \cdot 1\end{array}$ & $\begin{array}{l}1.52 \pm 0.05 \\
1.69 \pm 0.04 \\
1.41 \pm 0.04\end{array}$ & $\begin{array}{l}25 \cdot 0 \pm 2 \cdot 0 \\
22 \cdot 6 \pm 1 \cdot 8 \\
21 \cdot 6 \pm 2 \cdot 0 \\
26 \cdot 6 \pm 2 \cdot 6 \\
24 \cdot 9 \pm 2 \cdot 9 \\
27 \cdot 3 \pm 4 \cdot 1\end{array}$ & $\begin{array}{l}3 \\
3 \\
1 \\
4 \\
2\end{array}$ & $\begin{array}{l}0 \\
2 \\
3 \\
7 \\
3\end{array}$ \\
\hline
\end{tabular}

Conversion: SI to traditional units-Serum $\mathrm{T} 4: 1 \mathrm{nmol} / 1 \approx 0.08 \mu \mathrm{g} / 100 \mathrm{ml}$. Serum $\mathrm{T} 3: 1 \mathrm{nmol} / 1 \approx 0.7 \mathrm{ng} / \mathrm{ml}$. concentrations in 1972 and in those remaining euthyroid and available for study during 1974-7. In contrast to the raised TSH group, five years elapsed before a single patient with a normal serum TSH concentration in 1972 developed hypothyroidism. This patient's TSH concentration was raised for two years before the onset of hypothyroidism. Raised serum TSH concentrations were recorded in 19 of the 61 patients in the original normal TSH group during the study. Ten patients were lost to follow-up, three of whom died.

At each stage of follow-up the mean serum total T4 concentration was significantly lower in the original raised TSH group than in the normal TSH group ( $P<0.001$ on each occasion). Although at all stages the mean serum total T3 concentration was lower in the raised serum TSH group than in the normal TSH group, the difference was significant only in $1975(\mathbf{P}<0.001)$.

\section{Discussion}

These results confirm that raised serum TSH concentrations may persist for years in euthyroid patients. ${ }^{6} 7$ There is, however, a yearly incidence of hypothyroidism of $2-6 \%$ in such patients, and it is apparent that yearly review of thyroid function, as occurs at present in all patients given iodine-131 for thyrotoxicosis, is necessary in euthyroid patients with raised serum TSH concentrations. In contrast, euthyroid patients with normal TSH values after radioiodine treatment are at much less risk of developing hypothyroidism, the single case in our series occurring only after five years had elapsed. Since patients with normal serum TSH concentrations constitute roughly half of all euthyroid patients after iodine-131 treatment there is much scope for reducing the review commitment of the endocrine clinic or the computerised follow-up programme. ${ }^{8} 9$

It is tempting to suggest that euthyroid patients with normal serum TSH concentrations need to be reviewed only every five years. During our study, however, 19 of the 61 patients in the original normal TSH group developed raised serum TSH concentrations and presumably an increased risk of subsequent hypothyroidism. It was perhaps fortuitous that five years elapsed before a patient in this group developed hypothyroidism, as this might have occurred earlier. We therefore estimate the serum TSH concentration one year after treatment when the early high incidence of hypothyroidism is passed. Euthyroid patients with raised serum TSH concentrations are reviewed yearly, as has been the case for all patients treated with radioiodine in the past, but euthyroid patients with normal concentrations are reviewed once every three years.

There are two other methods of reducing the follow-up commitment to radioiodine-treated thyrotoxic patients. On the one hand intentional ablation with iodine-131 may be used in Graves's disease, resulting in a $92 \%$ incidence of hypothyroidism at six months, ${ }^{10}$ although such a policy has not gained widespread acceptance. On the other hand euthyroid patients with raised serum TSH concentrations could be given thyroxine replacement therapy before overt hypothyroidism develops. Indeed, the euthyroid state of these patients may be questionable, since the mean serum total T4 concentrations are undoubtedly lower than those of similarly treated patients with normal serum TSH values and there is no compensatory increase in circulating total T3. Possibly the hypothalamic-

TABLE II-Mean serum total T4, T3, and TSH concentrations $( \pm S E)$ in euthyroid patients with normal serum TSH concentrations in 1972 and in patients remaining with normal serum TSH concentrations and available for study over next five years (all treated with iodine-131 for thyrotoxicosis between 1954 and 1966)

\begin{tabular}{|c|c|c|c|c|c|c|c|}
\hline Year & $\begin{array}{c}\text { No of } \\
\text { patients }\end{array}$ & $\underset{(\mathrm{nmol} / \mathrm{l})}{\text { Serum } \mathrm{T}}$ & $\underset{(\mathrm{nmol} / \mathrm{l})}{\text { Serum T3 }}$ & $\underset{(\mathrm{mU} / 1)}{\operatorname{Serum} \mathrm{TSH}}$ & $\begin{array}{c}\text { No developing } \\
\text { overt } \\
\text { hypothyroidism }\end{array}$ & $\begin{array}{l}\text { No developing } \\
\text { raised serum TSH } \\
\text { concentrations }\end{array}$ & $\begin{array}{l}\text { No lost to } \\
\text { follow-up }\end{array}$ \\
\hline $\begin{array}{l}1972 \\
1974^{*} \\
1975 \\
1976 \\
1977\end{array}$ & $\begin{array}{l}61 \\
58 \\
47 \\
40 \\
31\end{array}$ & $\begin{array}{r}113 \cdot 0 \pm 4 \cdot 0 \\
105 \cdot 0 \pm 3 \cdot 0 \\
105 \cdot 0 \pm 4 \cdot 0 \\
102 \cdot 0 \pm 3 \cdot 5 \\
98 \cdot 0 \pm 4 \cdot 0\end{array}$ & $\begin{array}{l}1.73 \pm 0.05 \\
1.77 \pm 0.04 \\
1.46 \pm 0.05\end{array}$ & $\begin{array}{l}4.0 \pm 0.2 \\
4.1 \pm 0.3 \\
3.9 \pm 0.3 \\
3.6 \pm 0.3 \\
3.6 \pm 0.4\end{array}$ & $\begin{array}{l}0 \\
0 \\
0 \\
1\end{array}$ & $\begin{array}{l}3 \\
6 \\
5 \\
5\end{array}$ & $\begin{array}{l}0 \\
5 \\
2 \\
3\end{array}$ \\
\hline
\end{tabular}

*Patients with normal serum TSH concentrations in 1972 were not studied in 1973.

Conversion: SI to traditional units-Serum T4: $1 \mathrm{nmol} / 1 \approx 0.08 \mu \mathrm{g} / 100 \mathrm{ml}$. Serum T3: $1 \mathrm{nmol} / 1 \approx 0.7 \mathrm{ng} / \mathrm{ml}$. 
pituitary-thyroid axis no longer functions as an intact unit in such patients, since the irradiated thyroid may be unable to respond to endogenous $\mathrm{TSH}$ by increasing thyroid hormone secretion. The raised serum TSH concentration may simply indicate inadequate amounts of circulating thyroid hormones.

A further argument for giving thyroxine replacement therapy to euthyroid patients with raised serum TSH concentrations after iodine-131 is the possibility that such patients if left untreated might be at increased risk of ischaemic heart disease, as occurs in autoimmune thyroiditis. ${ }^{11}$ Such a decision would be justified, however, only if the association between autoimmune thyroiditis and ischaemic heart disease, which is at present unknown, was to be mediated via raised serum TSH and suboptimal thyroid hormone concentrations rather than other possible factors such as hypercholesterolaemia ${ }^{12}$ and circulating immune complexes. ${ }^{13}$ If thyroxine is to be administered to clinically euthyroid patients with raised serum TSH concentrations it must be given with caution. About half of all patients treated with iodine-131 for thyrotoxicosis have circulating TSH receptor antibodies, ${ }^{14}$ and thus the thyroid remnant, although unable to sustain normal output of thyroid hormones, may be functioning autonomously and not under the control of endogenous TSH. Thyroxine therapy would be additive to the remnant production of thyroid hormones in some patients, and if the average replacement of $0 \cdot 15 \mathrm{mg}$ daily was to be given ${ }^{15}$ thyrotoxicosis might be induced. It should also be borne in mind that, in theory at least, the dose of thyroxine required might vary from time to time in individual patients as the presence and titre of TSH receptor antibodies fluctuates.

\section{References}

1 Slingerland, D W, et al, fournal of Clinical Endocrinology and Metabolism, $1972,35,912$.

2 Toft, A D, et al, British Medical fournal, 1974, 3, 152.

3 Seth, J, et al, Clinical Chimica Acta, 1976, 68, 291.

4 Irvine, W J, et al, Clinical Endocrinology, 1973, 2, 135.

${ }^{5}$ Toft, A D, et al, New England Fournal of Medicine, 1978, 298, 643.

6 Tunbridge, W M G, et al, British Medical fournal, 1974, 3, 89.

7 Toft, A D, et al, Lancet, 1975, 2, 576.

${ }^{8}$ Hedley, A J, et al, British Medical fournal, 1970, 1, 556.

${ }^{9}$ Boyle, C M, British Medical fournal, 1974, 2, 490.

10 Wise, P H, et al, Lancet, 1975, 2, 1231.

${ }^{11}$ Bastenie, P A, et al, Lancet, 1977, 2, 155.

12 Fowler, P B S, Proceedings of the Royal Society of Medicine, 1977, 70, 297.

$13 \mathrm{Al}-\mathrm{Khateeb}, \mathrm{S} \mathrm{F}$, et al, fournal of Clinical and Laboratory Immunology, 1978, 1, 55.

${ }_{14}$ Mukhtar, E D, et al, Lancet, 1975, 1, 713.

15 Evered, D, et al, British Medical fournal, 1973, 3, 131.

(Accepted 18 August 1978)

\title{
The social toll of Crohn's disease
}

\author{
B G GAZZARD, H L PRICE, G W LIBBY, A M DAWSON
}

British Medical fournal, 1978, 2, 1117-1119

\section{Summary and conclusions}

Eighty-five outpatients with Crohn's disease who knew their diagnosis and that the disease was subject to relapse were interviewed. The personalities of the women as measured by the Eysenck personality questionnaire were similar to those of a control group, but the men were more neurotic and introverted. Most patients continued to live optimistic, useful lives; they felt well, continued to work, hoped that their disease would not deteriorate in the future, and often had an improved relationship with their spouse despite less frequent sexual intercourse.

We found that the successful adaptation of patients to this chronic disease was more closely related to their personality than to the activity or extent of the disease.

\section{Introduction}

Crohn's disease is a life-long disabling condition that often necessitates multiple operations and prolonged drug treatment.

\section{Westminster Hospital, London SW1P 2AP}

B G GAZZARD, MD, MRCP, consultant gastroenterologist

Scarborough General Hospital, Scarborough, Toronto, Canada

H L PRICE, MD, FRCPC, consultant gastroenterologist

St Bartholomew's Hospital, West Smithfield, London EC1A 7BE

G W LIBBY, DPM, MRCPSYCH, senior registrar, department of psychological medicine

A M DAWSON, MD, FRCP, consultant gastroenterologist
When told of the diagnosis many patients are anxious to know how the condition will affect their life. Although detailed longitudinal studies of the clinical course of Crohn's disease have been reported, little information is available about the effect of the disease on the social, marital, and sexual lives of the patients and on their financial problems. We therefore undertook a survey of these aspects of the lives of patients with long-standing disease.

\section{Patients and methods}

All patients who had suffered from Crohn's disease for more than one year and attended the medical gastroenterology clinic between July and December 1976 were interviewed by a doctor who already knew them well, and enough time was given for them to be able to express themselves freely and at length. A form with questions about their knowledge of the disease, work record, married and sexual life, and financial problems was filled in for each patient. They were also asked a series of general questions about their ambitions and worries and how they saw their future. All patients completed a form to estimate their morbid anxiety index ${ }^{1}$ (MAI) and an Eysenck personality questionnaire $^{2}$ (EPQ). In calculating the MAI we excluded the question relating to bowel action and frequency. The degree of activity of Crohn's disease (disease activity) was assessed by a combination of clinical and biochemical features that we have previously found useful. While the potential maximum score on this index is 46 , most patients scoring above 10 have extensive active disease. ${ }^{3}$

Statistical analyses were performed using the Spearman ranking correlation coefficient unless otherwise stated.

\section{Results}

The 85 patients (28 male and 57 female) were aged 14-71 (mean 35.6 ) years. The duration of illness varied from one to 22 (mean 11) years. Over half the patients had disease in both the large and small 